\title{
Retroperitoneal schwannoma: an unusual cause of abdominal distention
}

\author{
Christopher Holbrook, Nasir Saleem
}

Department of Internal Medicine, Presence St Joseph Hospital, Chicago, Illinois, USA

Correspondence to Nasir Saleem,

nasirsaleemmd@gmail.com, nasirsaleemmd@gmail.com

Accepted 27 April 2017

\section{DESCRIPTION}

A 54-year-old Caucasian woman with no significant medical history presented to her primary care physician with chief complaints of right-sided abdominal dull pain and distension. There were no constitutional symptoms or other complaints such as nausea, vomiting, constipation, diarrhoea, melena or hematochezia. She was a non-smoker with no

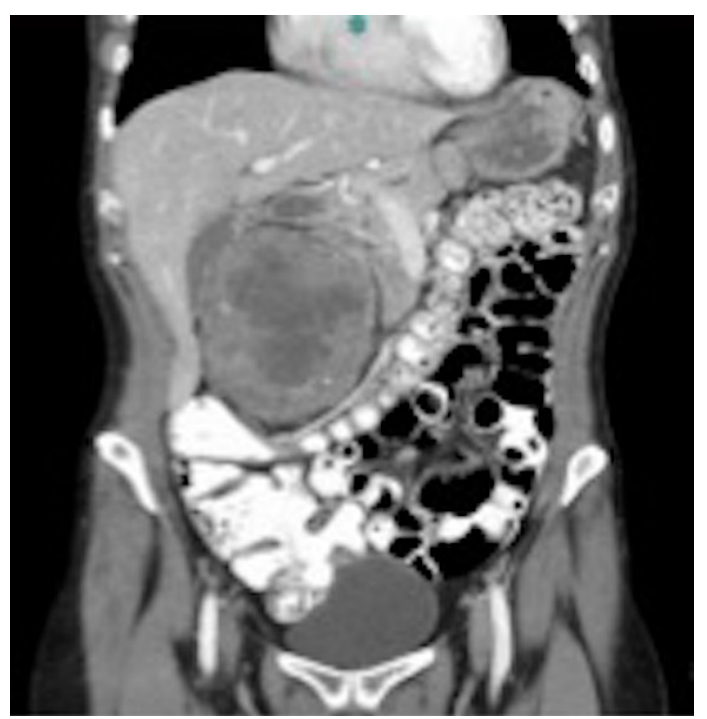

Figure 1 Coronal CT image of the abdomen reveals a large heterogeneous mass that contains areas of necrosis in the retroperitoneum inferior to the right kidney. This mass measures approximately $11.0 \times 8.5 \times 8.3 \mathrm{~cm}$ and displaces the adjacent structures, including the inferior vena cava and small bowel.

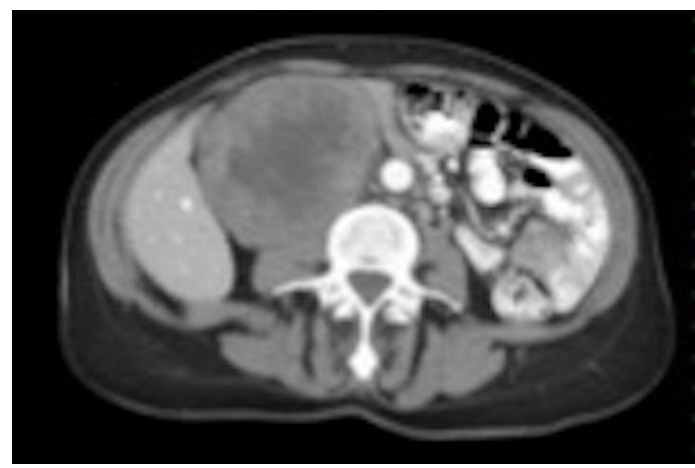

Figure 2 Transverse CT image of the abdomen reveals a large heterogeneous mass that contains areas of necrosis in the retroperitoneum inferior to the right kidney. This mass measures approximately $11.0 \times 8.5 \times 8.3 \mathrm{~cm}$ and displaces the adjacent structures, including the inferior vena cava and small bowel.

\section{Learning points}

- Schwannomas are mesenchymal tumours that arise from Schwann cells of peripheral nerve sheaths and can occur in all age groups. More than $90 \%$ of schwannomas are benign, and the most commonly involved sites are the head, neck and extremities. Only $1 \%-3 \%$ of schwannomas are found in the retroperitoneal space.

- Retroperitoneal schwannomas are mostly asymptomatic and found incidentally unless they grow large enough to cause compressive symptoms. The retroperitoneum is non-restrictive, so that benign tumours, such as schwannomas, are often able to grow to a large size before causing symptoms, which are usually vague and non-specific. CT and MRI findings show characteristic features such as a well-demarcated, homogeneous, spherical, solitary mass, but none are specific. Secondary degenerative changes, including cyst formation, calcification, haemorrhage and hyalinisation, can occasionally occur. ${ }^{2}$ This was also seen in our patient, where a large heterogeneous mass with areas of necrosis was seen on imaging. Other diagnoses such as paraganglioma, neurofibroma, ganglioneuroma and retroperitoneal malignancies, such as malignant fibrous histiocytoma, lymphoma and liposarcoma, should be considered.

- Surgical resection is the optimal treatment for retroperitoneal schwannomas. ${ }^{3}$ Preoperative diagnosis is challenging and a definitive diagnosis can only be made postoperatively by histopathological and immunohistochemical analyses of surgical specimens. Benign retroperitoneal schwannomas generally have good prognosis after complete resection with a low risk of tumour recurrence. ${ }^{2}$ Schwannomas should be included in the differential diagnosis of any retroperitoneal abdominal mass.

significant family history. Vital signs were stable and physical exam was insignificant except for dull pain on deep palpation of the right mid-abdomen. Laboratory studies including complete blood count, basic metabolic panel, liver function tests, serum amylase and serum lipase were all within normal range. CT of the abdomen revealed a large retroperitoneal mass which was concerning for a malignant sarcoma (figures 1 and 2). Positron emission tomography scan confirmed increased metabolic 


\section{Images in...}

activity within the mass but no other areas of increased radiolabelled fluorodeoxyglucose uptake. She underwent radical resection of the mass by laparotomy, and pathology was consistent with benign schwannoma. No further treatment was necessary and the patient remained asymptomatic with no evidence of recurrence 1 year later.

Contributors $\mathrm{CH}$ and NS were equally involved in the concept, literature review and compilation of this case report.

Competing interests None declared.

Patient consent Obtained.
Provenance and peer review Not commissioned; externally peer reviewed.

(C) BMJ Publishing Group Ltd (unless otherwise stated in the text of the article) 2017. All rights reserved. No commercial use is permitted unless otherwise expressly granted.

\section{REFERENCES}

1 Fass $G$, Hossey $D$, Nyst $M$, et al. Benign retroperitoneal schwannoma presenting as colitis: a case report. World J Gastroentero/ 2007;13:5521-4.

2 Xu SY, Sun K, Xie HY, et al. Hemorrhagic, calcified, and ossified benign retroperitoneal schwannoma: first case report. Medicine 2016;95:e4318.

3 Rajkumar JS, Ganesh D, Anirudh JR, et al. Laparoscopic excision of Retroperitoneal Schwannoma. J Clin Diagn Res 2015;9:PD05-7.

Copyright 2017 BMJ Publishing Group. All rights reserved. For permission to reuse any of this content visit

http://group.bmj.com/group/rights-licensing/permissions.

BMJ Case Report Fellows may re-use this article for personal use and teaching without any further permission.

Become a Fellow of BMJ Case Reports today and you can:

Submit as many cases as you like

- Enjoy fast sympathetic peer review and rapid publication of accepted articles

- Access all the published articles

Re-use any of the published material for personal use and teaching without further permission

For information on Institutional Fellowships contact consortiasales@bmjgroup.com

Visit casereports.bmj.com for more articles like this and to become a Fellow 